\title{
Building Italian Menton, 1940-1943: urban planning and Italianization
}

\author{
NIALL MACGALLOWAY \\ niallmacgalloway@gmail.com
}

\begin{abstract}
The Italo-French armistice of July 1940 brought an end to the brief period of conflict between Italy and France that had taken place after Mussolini's declaration of war in June of the same year. Disappointing Italian military performances left Italy with only a small strip of territory on the Italo-French border to occupy until the expansion of the occupation zone in November 1942. This article will explore urban planning projects in the largest of the Italianoccupied towns, Menton. It will argue that Italian urban planning projects formed a crucial layer of the long-term Italianization of the town and were indicative of wider Italian plans in the event of an Axis victory. It will demonstrate that hitherto underexplored post-war plans reveal not only how Italian planners hoped to reshape the region, but also how planners hoped that these changes would bind territories physically to Italy.
\end{abstract}

When Italy and France signed an armistice at the Villa Incisa outside Rome on 24 June 1940, the Italian armed forces were allowed to occupy all territory currently held in all theatres of operation. ${ }^{1}$ In France, this territory amounted to around 80,000 hectares and a handful of border communes in the Alpes-Maritimes, Savoie and Haute-Savoie. ${ }^{2}$ The only town of any size occupied by Italian troops prior to the expansion of the zone in November 1942 was Menton, which had undergone an extensive evacuation leaving the town all but deserted. ${ }^{3}$ This article aims to explore Italian construction and urban regeneration projects within the town. It

${ }^{1}$ Documents diplomatiques françaises, 1940: Les armistices de juin 1940 (Brussels, 2003), doc. 91, 'Convention d'armistice avec l'Italie', 167-73; I Documenti Diplomatici Italiani (DDI), 9th series, V, doc. 95, 'Convenzione di armistizio tra il capo di Stato Maggiore, Generale italiano, Badoglio, ed il capo della Delegazione francese per l'armistizio, Hunzinger [sic]', 24 Jun. 1940, 76-82; R.H. Rainero, Mussolini e Pétain: Storia dei rapporti tra l'Italia e la Francia di Vichy (10 giugno 1940 - 8 settembre 1943) (Rome, 1992), II, doc. 5, 'Testo definitive della Convenzione di Armistizio tra l'Italia e la Francia', 24 Jun. 1940, 58.

${ }^{2}$ D. Schipsi, L'occupazione italiana dei territori metropolitani francesi, 1940-1943 (Rome, 2007), $12-13$.

${ }^{3}$ The plans for the evacuation of the border communes can be found in the Archives Départementales des Alpes-Maritimes (ADAM). See in particular ADAM 0030W 0057, 'Le Maire de Roquebrune-Cap-Martin à Monsieur le Préfet des Alpes-Maritimes', 27 May 1940; ADAM 0030W 0057, 'Le Préfet des Alpes-Maritimes à Monsieur l'Ingénieur en Chef 
will argue that these projects reveal a further layer to the idea that Menton and the other towns were being subjected to annexationist policies, rather than simply occupied. For Italy, many of these projects were undertaken in order to alter the economy and infrastructure of the town in an effort to focus these factors towards Italy, rather than towards France. Although many of these projects remained unfinished, or as in the case of many of the larger projects were not commenced, by the time of Italy's surrender in September 1943, they remain an important indication of Italy's aspirations for a post-war Europe. In this sense, this article echoes Davide Rodogno's sentiment that Fascism's failures must be examined as an indication of its ambitions. $^{4}$

\section{Menton under the occupation}

The idea that Menton was subjected to a de facto annexation is neither new nor controversial. In the weeks immediately following the occupation, Italian officials issued the 'Bando del Duce', imposing Italian law, language, currency and government on the annexed communes. ${ }^{5}$ The legality of this document was fiercely challenged by the French authorities, who argued that Italian officials were overstepping their authority and breaking the clauses of both the armistice and the Hague Convention of $1907 .{ }^{6}$ In reality, the occupied communes found themselves in a state of legal limbo. Italy argued that it was permitted to occupy the region until a peace treaty had been signed, and that the armistice gave it 'tous les droits de la Puissance occupante'. ${ }^{7}$ Although the legality of the situation was extensively questioned, by July 1941 French officials privately acknowledged that Italy's occupation of the territories bore 'all the characteristics of an annexation'. ${ }^{8}$ Indeed, initial stages of annexation highlighted by French officials included the changing of street names and signs on buildings from French to Italian, and the alteration of signposts to measure distances from Rome. ${ }^{9}$ Although French authorities continued to mount legal challenges to Italian measures in the occupied communes,

des Ponts-et-Chaussées', 8 Jun. 1940; ADAM 0030W 0057, 'Le Trésorier-Payeur Général à Monsieur le Préfet des Alpes-Maritimes', 20 Aug. 1940.

${ }^{4}$ D. Rodogno, Fascism's European Empire: Italian Occupation during the Second World War (Cambridge, 2006), 2. Rodogno quotes Enzo Collotti and Renzo De Felice as having made similar statements in their own work.

${ }_{6}^{5}$ Rainero, Mussolini e Pétain, II, doc. 9, 'Bando del Duce sui territori occupati', 91-100.

${ }^{6}$ Archivio Storico dell'Ministero degli Affari Esteri (ASMAE), GABAP, b. 20, 'Note de Renseignements', 15 May 1942; Archives Nationales (AN) AJ 41 2302, 'Conference Interministerielle du 18 decembre 1941', 22 Dec. 1941; ASMAE, GABAP, b. 20, 'Note de Renseignements', 10 Jun. 1942.

7 DDI, 9th series, V, doc. 95, 'Convenzione di armistizio', 24 Jun. 1940, 82; AN AJ 41 1182, 'La problème italienne', undated document; ASMAE, GABAP, b. 20, 'Appunto', 31 Jul. 1942, quoted in French in the original Italian document.

8 AN AJ 41 2302, 'Occupation de Menton par l'Armée italienne, Note de Renseignements', 28 Jul. 1941.

${ }^{9}$ Ibid. 
arguing that under the Hague Convention, Italy's rights were restricted merely to maintaining public life, there was little that France could do to impose its legal rights without reopening hostilities between the two countries. ${ }^{10}$ Existing secondary literature has accepted this idea of a de facto annexation. Davide Rodogno has argued that Italian planners pursued policies in Menton similar to those in the annexed Yugoslav territories, believing both to be equally part of the spazio vitale, whilst Jean-Louis Panicacci has argued that Menton was certainly the most Italianized of the French communes. ${ }^{11}$ Secondary literature, however, has not fully analysed the physical changes in Menton. Jean-Louis Panicacci's works dedicated to Menton's experience of occupation do not mention urban planning projects at all. ${ }^{12}$ To compound this problem, the fact that many of these works remained at a planning stage has resulted in a complete dearth of lieux de mémoire or examples of Italian construction projects. ${ }^{13}$ Whilst work on Italian urban planning and construction is both plentiful and laudable, the majority of these works focus on Rome itself or on the collection of cities that Mussolini's regime constructed on the reclaimed Pontine Marshes. ${ }^{14}$ This, in a sense, should not be surprising. In a regime that loosely modelled itself on the Roman empire, the city represented the living embodiment of romanità. ${ }^{15}$ This focus on Rome, however, has ignored urban planning projects that continued into the war years. Aristotle Kallis has noted that 'first the war and then the collapse of the regime in 1943 arrested the frenetic pace of demolition and (re)construction in [Rome] that had gathered a seemingly unstoppable momentum in the $1930 \mathrm{~s}^{\prime}{ }^{16}$ Whilst it is certainly true that the outbreak of war prompted a halt to the large-scale urban reconstruction projects in Rome, in Italy's occupied French communes, engineers and architects sketched images of post-war Menton stretching decades into the future. Although actual construction failed to take off on the scale of Rome, blueprints and projects were

10 AN AJ 41 2302, 'La problème italienne', n.d. Although one report suggests that the only way to 'solve' the issue of Menton was for the French armed forces to retake the town, there is no evidence to suggest that such an idea was taken seriously; see AN AJ 41 2302, 'Occupation de Menton par l'Armée italienne. Note de Renseignements', 28 Jul. 1941.

${ }^{11}$ Rodogno, Fascism's European Empire, 273; J.-L. Panicacci, L'occupation italienne, sud-est de la France, juin 1940 - settembre 1943 (Rennes, 2010), 54.

12 J.-L. Panicacci, Menton dans la tourmente, 1939-1945 (Menton, 1984); J.-L. Panicacci, 'Menton et les Mentonnais, 1939-1945', Recherches Régionales, 75 (1981), 3-35.

13 S. Frediani, 'Les lieux de mémoire à Menton de 1860 à nos jours', Recherches Régionales, 162 (2002), provides a summary of plaques and monuments in Menton from World War II. Unsurprisingly, the resistance and the deportations dominate memory and the lieux de mémoire in the town.

14 A.A. Kallis, The Third Rome, 1922-1943: The Making of a Fascist Capital (Basingstoke and New York, 2014); P. Baxa, Roads and Ruins: The Symbolic Landscape of Fascist Rome (Toronto, Buffalo and London, 2010); B.W. Painter, jr, Mussolini's Rome: Rebuilding the Eternal City (Basingstoke, 2005); J. Arthurs, Excavating Modernity: The Roman Past in Fascist Italy (Ithaca, 2012); A. Muntoni, Roma tra le due guerre, 1919-1944: architettura, modelli urbani, linguaggi della modernità (Rome, 2010).

15 Baxa, Roads and Ruins, 3.

${ }^{16}$ Kallis, The Third Rome, 42. 
discussed and drawn up at length. In addition, the repair and wholescale replacement of infrastructure adds weight to the argument that Italy was not simply occupying the territories captured by its troops in 1940, but was annexing them. Indeed, if Paolo Nicoloso argues that the war put paid to the realization of Fascism's urban construction, then continued planning into 1941 and 1942 demonstrates that the war did not bring a halt to Fascism's hopes of a cohesive architectural vision. ${ }^{17}$ This article will argue that these construction projects were designed to integrate physically the territories with Italy, providing a structural and architectural legacy that had parallels in other Italian territories. Moreover, it will argue that the prioritization of these projects over other more practical military uses for these finances demonstrates how seriously Fascism took these plans. As such, the territories should be considered an important part of Fascism's Ordine nuovo.

\section{Restoring normality}

The primary goal of the newly installed Italian administration was to return Menton to a fully functioning town. Simultaneously, however, Italian officials saw the occupation as an opportunity to remould and alter Menton's status within Italy. One Italian official likened the town's pre-war status to that of a 'parasite', overly dependent upon tourists and hivernants. ${ }^{18}$ Although Italy's exit from the war in 1943 ended this debate before urban planners could fully address the position that the town would take in post-war Europe, there were clear indications that long-term plans were considered as early as 1940. Whilst Fascist political theorists failed to find complete consensus on how an Axis-dominated Europe would look, the majority agreed that territories around Nice, including Menton, would be annexed to Italy. ${ }^{19}$ Although it is uncertain to what degree Italian officials involved in local government were aware of the more intricate details of these plans, it is clear from the actions taken by these officials described below that the broader ambition of annexing the town was known.

The decision to embark upon a series of infrastructural projects was at least partially borne from necessity. The decision made by France to switch off the Nizzardo aqueduct, which had previously supplied much of the Côte d'Azur with water, prompted the newly installed

17 P. Nicoloso, Mussolini architetto: propaganda e paesaggio urbano nell'Italia fascista (Turin, 2008), 271. Although the sentiment is made in Nicoloso's study, the emphasis is mine.

18 Archivio Centrale dello Stato (ACS), MI, DGPS, DAGR, A5 II ${ }^{\mathrm{a}}$ guerra mondiale, b. 119, fasc. 66, 'Il Commissario per i Servizi Polizia Frontiera II Zona, P. Bologensi, all'Eccellenza il Capo della Polizia, Roma', 5 Oct. 1940.

19 D. Rodogno, 'Le nouvel ordre fasciste en Méditerranée, 1940-1943: présupposés, idéologiques, visions, et velléités', Revue d'histoire modern et contemporaine, 55 (2008), 145. 
Italian administration to examine long-term solutions. ${ }^{20}$ Italian engineers highlighted that without the Nizzardo aqueduct, only one smaller aqueduct and three small wells provided the town's entire water supply. Engineers suggested constructing at least two or three additional wells, at an estimated cost of 300,000-380,000 lire. ${ }^{21}$ This suggestion followed recommendations that damaged pipes crossing the Pont de l'union be repaired, having been rendered inoperable since the street fighting for Menton in June 1940. ${ }^{22}$ Although not suggested simultaneously, these projects reveal part of a wider desire to provide a long-term solution for water shortages. Still more substantial was the list of repairs required to bring the town's main water pump back into operation. Engineers highlighted that the peak voltage of the Ausonia pump regularly fell to 160 volts, a completely insufficient level to power the town's water supply. ${ }^{23}$ Other water pumps, including the Sacro Cuore water pump, were also underpowered, resulting in a delay in distribution and an intermittent supply. ${ }^{24}$

There was nothing unusual in the Italian desire to establish a more reliable water supply in Menton, and indeed many military tacticians might have argued that this aim made good logistical sense. Italian plans, however, reveal that repairs and the construction of additional facilities were often focused on the post-war future, rather than the immediate needs of the armed forces. One Italian engineer stated that 200 litres daily was the required volume of water per person, noting that this estimate took into account the amount required for hotel guests as well as permanent residents. ${ }^{25}$ The same document went on to state that figures used to calculate water usage were based upon a population of 23,000, with greater numbers expected in the tourist season. ${ }^{26}$ Italian population estimates, however, noted that following the evacuation of the town, the population stood at 6,709 in May 1941, rising only to 8,445 residents by January $1943 .{ }^{27}$ Estimates, therefore, were not made simply to accommodate the population during the war, but were instead based upon the hope that

${ }^{20}$ Archives Municipales de Menton (AMM) 1O272, ‘Commissione Italiana di Armistizio con la Francia, Amministrazione dei Territori Francesi occupati', 10 Feb. 1943.

21 AMM 1O272, 'Commissione Italiana di Armistizio con la Francia, Approvvigionamento idrico della città di Mentone', 30 Jul. 1942; ACS, CIAF, b. 3, fasc. 59, 'Ricerca di acqua potabile nel sottosuole di Mentone', 12 Feb. 1943.

22 AMM 1O272, 'L'ingenere capo al Signor Commissario Civile', 24 May 1942; ACS, CIAF, b. 3, fasc. 59, 'Ufficio tecnico per l'acqua, il gas e l'elettricità, Relazione sull acquedotto di Mentone', 21 Oct. 1941.

23 AMM 1O272, 'L'ingenere capo al Signor Commissario Civile', 16 Jun. 1942.

24 ACS, CIAF, b. 3, fasc. 59, 'Ufficio tecnico per l'acqua, il gas e l'elettricità, Relazione sull'acquedotto di Mentone', 21 Oct. 1941.

25 AMM 10272, 'Commissariato Civile di Mentone, Ufficio Tecnico per l'Acqua, il Gas e l'Elettricità, Rifornimento idrico', 30 Jul. 1942.

${ }^{26}$ Ibid.

27 ACS, MI, DGPS, DAGR, A5 II a guerra mondiale, b. 119, fasc. 66, 'Il Prefetto [d'Imperia] al Ministro dell'Interno, Direzione Generale della PS', 13 May 1941; ACS, CIAF, b. 1, fasc. 1, 'Relazione sull'attività del Commissariato Civile di Mentone per il periodo 1 giugno 1942 - 31 gennaio 1943, Per contribuire alla storia dell'Armistizio Italo-Francese'. These figures 
Menton would become a tourist destination again. Although the Italian government wished to stabilize the town, it is highly unlikely that Italian officials would have invested in the tourist trade unless there existed hopes that this trade would somehow benefit the Italian economy in the post-war future.

These planned repairs, moreover, went far beyond simply stabilizing immediate needs. The Italian civil commissioner for the town by 1943, Gino Berri, noted that the cost of pipes, electro mechanical parts and installation costs for the pumps alone would come to almost 500,000 lire. ${ }^{28}$ Italian engineers, on the other hand, recommended a budget of 900,000 lire. ${ }^{29}$ These sums of money to be spent on an occupied territory become even more incredible when placed into the context of the period. By 1943, the Italian economy was becoming increasingly strained by the costs of the war and the dearth of economic opportunities in a world hostile to the Axis. These plans cannot simply be written off as local officials 'working towards the Duce'. ${ }^{30}$ Many of these decisions were expensive enough that they had to be approved by central government organs in Rome. ${ }^{31}$ At this point in time, the entire annual budget of Menton was 4,460,500 lire, with a discretionary fund of 860,700 lire. ${ }^{32}$ Projected repairs on water pumps alone, therefore, would already have consumed the entire discretionary funding for the town, much of which had been spent on other projects. ${ }^{33}$ Nonetheless, the local Italian administration obviously considered the works to be essential, underlining engineers' recommendations in their reports that the works were valid in engineering terms. ${ }^{34}$ The decision to earmark valuable funds to construct wells and repair expensive water pumps in one occupied town, therefore, is only understandable if taken as part of a wider plan to annex the town permanently.

often did not take into account military personnel in the region, but did account for Italian officials, many of whom held military rank. It is difficult, therefore, to know exactly how many people were living in Menton during this period, but AMM 10272, 'Commissariato Civile di Mentone, Ufficio Tecnico per l'Acqua, Il Gas, e l'Elettricità, Rifornimento idrico', 30 Jul. 1942, suggests that a planned-for wartime population of 12,000 would be sensible.

28 ACS, CIAF, b. 3, fasc. 59, 'Il Commissario Civile, Gino Berri, al Commissario Straordinario del Comune di Mentone', 1 May 1943.

${ }^{29}$ ACS, CIAF, b. 3, fasc. 59, 'L'Ingenere Capo, A. Laudonio al Commissario Civile di Mentone', 30 Apr. 1943.

30 The phrase is Davide Rodogno's, Fascism's European Empire, 112, but is adapted from I. Kershaw, "Working towards the Führer': reflections on the nature of the Hitler dictatorship', Contemporary European History, 2 (1993), 103-18.

31 ACS, CIAF, b. 3, fasc. 59, 'Accordo per il Providimento del Servizio Distribuzione Acqua Potabile in Mentone', 21 Apr. [1943].

32 ACS, CIAF, b. 1, fasc. 1, 'Relazione sulla attività del Commissariato Civile di Mentone per il periodo 1 ottobre 1941 XIX - 31 maggio 1942 XX - Per contribuire alla storia dell'Armisitizio Italo-Francese', n.d.

${ }^{33}$ Additional projects championed by the Italian administration included numerous other urban regeneration projects described below, a drive for Italian tourists to visit the town and various schemes to encourage portions of the pre-war population to return to the town.

34 ACS, CIAF, b. 3, fasc. 59, 'L'ingenere capo, A. Laudonio al Commissariato Civile di Mentone', 30 Apr. 1943. 
Although it could be argued that ensuring an adequate water supply was an absolute necessity if the Italian government hoped to stabilize Menton, the option to construct wells and water pumps was one of the most expensive options available. The Compagnie Générale des Eaux, who had supplied the town with water prior to the occupation, was still prepared to supply Menton even under Italian control..$^{35}$ In April 1943, the Compagnie Générale des Eaux offered to supply Menton with 2,500 litres daily, a figure that could rise to 3,000 litres daily in 'exceptional circumstances'. ${ }^{36}$ This figure, however, was completely unsuitable if the Italian administration hoped to reach the target of 200 litres daily per person. ${ }^{37}$ Had the occupying administration been prepared to accept a lower and more realistic water usage per person, the combination of existing wells and the quantity supplied by the Compagnie Générale des Eaux might have been sufficient to supply the town. Instead, the decision to shun more economically viable and time-efficient solutions demonstrates the level to which the Italian administration was focused on the post-war future of the town.

Part of the decision to break Menton's reliance on French and Swiss water supplies was to bring the territories in line with Fascism's policy of autarky. A similar policy to that undertaken to ensure a reliable source of water was displayed when selecting gas and electricity supplies for the occupied communes. Prior to the outbreak of war, Menton and many of the other occupied communes were supplied by the French-based L'Énergie industrielle or the Swiss Compagnie Génévoise de l'industrie du gas. ${ }^{38}$ By 1943, the former had effectively increased prices by charging 0.4 lire per kilowatt hour instead of 0.4 francs, making a not insubstantial profit from the artificially overvalued lire. ${ }^{39}$ Despite broadly agreeing to the prices set by L'Énergie industrielle, Italian officials and engineers had been working on long-term plans to award energy contracts to Italian companies since $1941 .{ }^{40}$ In November 1941, Italian administrators awarded at least part of the town's gas contract to the Turin-based Società italiana per il gas, at the expense of the Compagnie Génévoise de l'industrie du gas. ${ }^{41}$ By 1942,

35 AMM 1O272, 'L'ingegnere capo al Signor Commissario Civile', 25 Nov. 1941.

36 ACS, CIAF, b. 3, fasc. 59, 'Accordo per il Providimento del Servizio Distribuzione Acqua Potabile in Mentone', 21 Apr. [1943].

37200 litres daily per person drawing from a supply of 3,000 litres of water per day would only be suitable for a population of around 15 people.

38 ACS, CIAF, b. 2, fasc. 55, 'Il Commissario Civile, Gino Berri, alla Commissione Italiana di Armistizio con la Francia', 1 Apr. 1943; AMM 1O272, 'L'ingegnere capo al Signor Commissario Civile', 25 Nov. 1941; AN AJ 41 2302, 'Monsieur le Secrétaire Général auprès du Chef du Gouvernement', 4 Jun. 1943.

39 ACS, CIAF, b. 2, fasc. 55, 'Ufficio tecnico per l'acqua, il gas e l'elettricità al Commissario Civile', 1 Feb. 1943. On the changing value of the lira-franc exchange rate, see ASMAE, GABAP, b. 13, 'L'Ispettore Generale Capo, Tommasso Lazzari, al Ministero degli Affari Esteri e al Ministero delle Finanze', 30 Jun. 1941.

40 ACS, CIAF, b. 2, fasc. 55, 'Il Commissario Civile, Gino Berri, all'Énergie industrielle', 15 Jan. 1943, shows Berri broadly agreeing to the pricing structure set by L'Énergie industrielle.

41 AMM 1O272, 'L'ingegnere capo al Signor Commissario Civile', 25 Nov. 1941. 
the Società Anonima DERPO di Savona, operating just across the ItaloFrench border in Ventimiglia, had been awarded part of the electricity contract. ${ }^{42}$ At the same time, the civil commissioner for Menton, Giuseppe Frediani, had made initial contact with Rome to suggest an extension of the electricity line from Ventimiglia. ${ }^{43}$ Whilst the tone of Frediani's correspondence with his engineers clearly demonstrates his eagerness to begin the project, they also reveal a degree of apprehension over costs. It is possible that Frediani's apprehension may also have been partially borne from the knowledge that an extension of Italian electrical lines would expand these projects from a purely local budget, to larger-scale and possibly national considerations, thereby limiting his own place in decision-making. Nonetheless, the correspondence does demonstrate a willingness by Frediani to spend the local budget on longer-term projects.

The re-establishment of water, gas and electricity in Menton, therefore, cannot simply be viewed as practical measures, but instead as part of a political programme to bind the town to Italy. When discussing the extension of the electricity line from Ventimiglia, Frediani made clear that although having French companies supply electricity to the town would be more practical, it was not preferable. ${ }^{44}$ When French and Swiss companies ceased to provide key utilities to the town, arrangements with Italian companies to provide replacement services for the region were put in place. One of the long-term goals of the regime was to stop using foreign suppliers of utilities and to award these contracts to Italian suppliers. This would take place as a transition rather than as a stark break. In January 1942, Frediani stated that although the restoration of pre-war arrangements with French companies was the cheapest and most practical solution, these had to remain severed as such arrangements were no longer compatible with Italy's status as an occupying power. ${ }^{45}$ Furthermore, for those civilians who chose to return to Menton, Italy's ability to provide basic utilities would be a way of measuring whether

${ }^{42}$ ACS, CIAF, b. 2, fasc. 55, 'Il Commissario Civile, Giuseppe Frediani, alla Commissione Italiana di Armistizio con la Francia', 30 Apr. 1942.

43 Ibid.; ACS, CIAF, b. 2, fasc. 55, 'L'ingengnere Capo al Commissario Civile [di Mentone]', 26 Mar. 1942. The suggestion is also mooted in AMM, 1O272, 'L'ingegnere capo al Signor Commissario Civile', 3 Apr. 1942. AN AJ 41 2302, 'Note pour l'Amiral, Situation de Menton', 28 Jul. 1941, shows that in 1941 the French believed that the Italian administration would almost certainly begin to supply gas to Menton from Ventimiglia as well.

44 ACS, CIAF, b. 2, fasc. 55, 'Il Commissario Civile, Giuseppe Frediani, alla Commissione Italiana di Armistizio con la Francia', 30 Apr. 1942; AN AJ 41 2150, 'Compte Rendu Sommaire de l'entretien entre l'Amiral Duplat et le Général Pintor, Président de la CIA le jeudi 29 août 1940 ', shows the president of the CIAF, Pietro Pintor, stating that those civilians living in the Italian-occupied communes in the Tarentaise region must not be reliant upon French electricity or water supplies for the same reasons.

45 ACS, CIAF, b. 2, fasc. 56, 'Il Commissariato Civile di Mentone alla Commissione Italiana di Armistizio con la Francia', 2 Jan. 1942; ACS, CIAF, b. 3, fasc. 58, 'Accordo per la ripresa del servizio di Distribuzione del gas [a] Mentone da parte della 'Compagnie Génévoise de l'Industrie du Gaz', 11 May 1943, stated that if Italy won the war, existing contracts inherited by the Italian government between French companies and Menton could simply be disregarded. 
the new administration could run the town effectively or not. ${ }^{46}$ By March 1942, Italian engineers admitted that the pre-war needs of the annexed communes were not being met and that without the extension of the electricity line from Ventimiglia these communes would experience perpetual shortfalls in electricity. ${ }^{47}$

This potential loss of prestige created by such shortages was not lost on Frediani, who made it clear that should the Italian administration return to pre-war foreign suppliers, it would be interpreted as a failure of the government adequately to provide basic utilities. ${ }^{48}$ As a result, Frediani firmly rejected any possible compromises put forward by his engineers, not only refusing to return to pre-war arrangements, but also refusing to enter into joint-supply ventures between companies on both sides of the border. ${ }^{49}$ These attempts to impose the ability of the Italian administration to provide these supplies and the place of this ability in obtaining prestige retained its importance as the conflict continued. Indeed, by February 1943 , Italian officials stated that water must be freely available for the visit of French representatives of the CIAF (Commissione Italiana d'Armistizio con la Francia - Italian-French Armistice Commission) to the town. ${ }^{50}$

It is perhaps no surprise that Italian planners valued an adequate water supply in particular so highly: for many Fascist urban planners, unopposed organic expansion of towns and cities had incubated disease and poor hygiene for which large-scale reconstruction was the only antidote. ${ }^{51}$ Moreover, Fascism's ability to deliver on the principles of urbanistica potentially carried a benefit in prestige. In the case of the visit of the CIAF officials noted above, the availability of water clearly demonstrated the way in which Italian governance had improved the town, and had done so without the assistance of French companies and officials. The introduction of Fascist urban planning to Menton served the dual purpose of applying the sciences of urbanistica, and tying the occupied communes to Italy in a binding and visually clear manner. Despite claims that Fascist urban planning and architecture in Italian East Africa to some extent remain a historical lacuna, it has received far more scholarly attention than plans to construct the Ordine nuovo in a physical sense in

${ }^{46}$ N. Wouters, N.W. Olesen and M. Conway, 'The war for legitimacy at the local level', in M. Conway and P. Romijn (eds.), The War on Legitimacy in Politics and Culture, 19361946 (Oxford and New York, 2008), 115, argues that the ability of local administrations to provide 'good government' was often a yardstick by which civilians measured the legitimacy of that government.

47 ACS, CIAF, b. 2, fasc. 55, 'L'ingenere Capo al Commissario Civile [di Mentone]', 26 Mar. 1942.

48 ACS, CIAF, b. 2, fasc. 56, 'Il Commissariato Civile di Mentone alla Commissione Italiana di Armistizio con la Francia', 2 Jan. 1942.

49 Ibid.

50 AMM, 1O272, 'Commissione Italiana di Armistizio con la Francia, al Dirigente dell'Ufficio Speciale del Genio Civile', 10 Feb. 1943.

51 D. Spiegel, 'Urbanism in Fascist Italy: all well and good?', in H. Bodenschatz, P. Sassi and M.W. Guerra (eds.), Urbanism and Dictatorship: A European Perspective (Basel, 2015), 46-7; Kallis, The Third Rome, 55-6. 
Europe. ${ }^{52}$ If we accept Ruth Ben-Ghiat's claim that tourist developments and large-scale urban planning schemes in Italy's colonial possessions were designed to create 'Italy's fourth shore', then these same schemes were used in Menton and the other occupied communes permanently to push Italy's frontier to incorporate these new territories..$^{53}$

Many of these developments were most likely planned as the first stage to further Italian expansion in France. In one document describing long-term urban changes to be made in Menton, proposals were made to expand the Rue de la République towards the sea, bisecting Place de la Conception. ${ }^{54}$ This plan was to be augmented by the extension of the Rue Henry Gréville towards what is now the Porte de France, creating two expansive parallel avenues. ${ }^{55}$ These avenues were designed to ease the flow of traffic between the Italian peninsula and the new Italo-French frontier beyond Menton. The planned construction of these large avenues demonstrated the particular architectural style that Italian officials hoped to impose on the town. Contemporary urban planning projects throughout Italy, for example the EUR ' 42 district in Rome, were also designed to incorporate large, open streets. ${ }^{56}$ The construction of these avenues, however, revealed the purpose Menton would serve in the Italian administration's post-war plans for the region: as part of a coastal strip connecting Turin and Genoa with Nice. ${ }^{57}$ This idea of Menton as a town which would receive increased levels of traffic between France and Italy was also revealed in the Italian administration's overhaul of the train station into an international station. ${ }^{58}$ The redevelopment of the train

52 The claim is made in A. González-Ruibal, 'Fascist colonialism: the archaeology of Italian outposts in western Ethiopia (1936-1941)', International Journal of Historical Archaeology, 14 (2010), 550-1. The author accepts that there is a great deal of scope left in this field to examine; however, work on Fascist urban planning in Africa can be seen in M. Fuller, Moderns Abroad: Architecture, Cities and Italian Imperialism (London, 2007); M. Antonsisch, 'Signs of power: Fascist urban ideologies in Ethiopia (1930s - 1940s)', GeoJournal, 52 (2000), 325-38; M. Fuller, 'Wherever you go, there you are: Fascist plans for the colonial city of Addis Ababa and the colonizing suburb of EUR '42', Journal of Contemporary History, 31 (1996), 397-418; M. Fuller, 'Building power: Italy's colonial architecture and urbanism, 1923-1940', Cultural Anthropology, 3 (1988), 455-87.

53 R. Ben-Ghiat, Fascist Modernities, 1922-1945 (Berkeley and London, 2001), 125.

54 AMM, 1O272, ‘Parere sul progetto di piano regolatore della città vecchia approvato con deliberazione municipale del 20 febbraio 1942 XX', 18 Apr. 1942. Street names in Menton underwent a series of changes by the Italian administration, but were often referred to by an Italianized form of their original names. As a result, Rue de la République, which would have been re-named under both Vichy and Fascist Italy, was referred to as Via della Repubblica in many Italian documents. This name would undoubtedly have been changed 55 Ibid.

56 G. Ciucci, Gli architetti e il fascismo: Architettura e città, 1922-1944 (Turin (1989), 182-3; Painter, jr, Mussolini's Rome, 22-5, makes a similar argument regarding the Via dell'Impero in Rome. For a general architectural discussion of the EUR ' 42 district, see Nicoloso, Mussolini architetto, 212-17.

57 Nice was frequently earmarked by Italian political theorists as Italy's minimum expectation of territorial compensation from France following a general peace treaty, see Rodogno, 'Le nouvel ordre fasciste en Méditerranée', 145.

58 AN AJ 41 2302, 'Note sur les revendications italiennes', 30 Sep. 1940. 
station to include offices for tax collection and passport control was seen as simply the first step to increasing the capability of the train station to deal with larger numbers of passengers. ${ }^{59}$ As late as 1942, the binding of much of the Alpes-Maritimes to the province of Imperia seemed to be championed by Italian planners, who stated that Nice would eventually form the entrance to that province. ${ }^{60}$ These planners stated that with the annexation of the Nizzardo to the Kingdom of Italy, traffic would notably change in the region, and that infrastructure between the incorporated French territories and Italy would have to be improved. ${ }^{61}$ Plans to expand the railway station at Menton and to construct two large boulevards in Menton, therefore, were part of a long-term project to bind the Côte d'Azur to Italy.

\section{Construction and Italianization}

These plans, however, also reveal that much of this work would necessarily take place after an Axis victory and final peace treaty. The expansion of the Rue de la République, for example, was given an overall timeframe of around 30 years, and would only take place upon the cessation of hostilities' ${ }^{62}$ Whilst exact figures on many hypothetical projects do not appear in the sources, engineers and urban planners were well aware that such projects would prove extremely expensive, and would have to be spread across many years. ${ }^{63}$ By 1943, Italian engineers noted that in order to accommodate essential utility works, building work in the streets and squares of the town would cost at least 240,000 lire. ${ }^{64}$ Although this does not match the recommended 900,000 lire budget for the construction of wells, it is interesting to note that these structural changes were allocated greater levels of funding than anti-aircraft defence. ${ }^{65}$ These costs were supplementary to costs such as the construction of schools, estimated at 100,000 lire, and the construction of a hospital costing 661,500 lire, which

59 AN AJ 4 438, 'Société Nationale des Chemins de fer française à Monsieur le Ministre [des Communications]', 28 Nov. 1940.

60 ASMAE, AP, Francia, b. 59, 'Amministrazione di Nizza', 19 Mar. 1942; Rodogno, Fascism's European Empire, 89-92, describes the planned creation of the new Italian province, Alpi Occidentali, following a successful Axis victory.

61 AMM 1O272, 'Parere sul progetto di piano regolatore della città vecchia approvato con deliberazione municipale del 20 febbraio 1942 XX', 18 Apr. 1942.

62 Ibid.

63 Ibid.

64 ACS, CIAF, b. 1, fasc. 39, 'Relazione sull'attività del Commissario Civile di Mentone per il periodo 1 giugno 1942 - 31 gennaio 1943, Per contribure alla storia dell'Armistizio ItaloFrancese'.

65 ACS, CIAF, b. 3, fasc. 59, 'L'Ingenere Capo, A. Laudonio al Commissario Civile di Mentone', 30 Apr. 1943; ACS, CIAF, b. 1, fasc. 39, 'Relazione sull'attività del Commissario Civile di Mentone per il periodo 1 giugno 1942 - 31 gennaio 1943, Per contribure alla storia dell'Armistizio Italo-Francese'. 
Italian officials noted included a maternity unit. ${ }^{66}$ In addition to these financial burdens, urban planners noted that the presence of various stages of building that had taken place over the years in the town and their interconnectedness was a particular obstacle. ${ }^{67}$

Nonetheless, Italian officials noted that these public works programmes would help integrate the town with Italy in both an architectural and communal sense. Those areas of the Menton demolished to make way for the expansion of the Rue de la République between the existing boulevard and the Place de la Conception would be remodelled to create a number of small open squares, reminiscent of Italian towns and cities. ${ }^{68}$ Moreover, areas of the old town which demonstrated a notably Italian architectural style would be incorporated into the changes, despite the fact that this would be considerably more expensive. ${ }^{69}$ This highlighting of existing Italian architecture - above all piazzas - was important in creating a physical narrative between the pre-French Menton and the Fascist annexation of the town, essentially parenthesizing the period of French rule. Indeed, Italian planners spoke of these projects to spotlight pre-existing Italian architecture as a 'restoration'.$^{70}$ It was anticipated that as the annexation became permanent, it would be possible to eradicate permanently signs of French influence on the physical appearance of the town. Urban planning projects in Rome had already set this trend of using building work to create a narrative, architecturally linking ancient and Fascist Rome. ${ }^{71}$ Yet the construction of buildings in both the Italian peninsula and Menton went further than simple architectural propaganda. The decision to allocate finances in militarily difficult times to areas such as schooling and maternity hospitals shows that Italian planners sought not only to redevelop Menton as a town, but to construct a community. It is not surprising that planners noted that demolitions that would come as a result of these projects would rid Menton of 'unsanitary' housing. Such developments would make way for more modern and 'hygienic' homes,

${ }^{66}$ ACS, CIAF, b. 1, fasc. 39, 'Relazione sull'attività del Commissario Civile di Mentone per il periodo 1 giugno 1942 - 31 gennaio 1943, Per contribure alla storia dell'Armistizio ItaloFrancese'.

67 AMM 1O272, 'Parere sul progetto di piano regolatore della città vecchia approvato con deliberazione municipale del 20 febbraio 1942 XX', 18 Apr. 1942.

$68 \mathrm{Ibid}$. On the construction and restoration of prominent piazzas in Rome, see Painter, jr, Mussolini's Rome, 73-5, 123.

69 AMM 1O272, 'Parere sul progetto di piano regolatore della città vecchia approvato con deliberazione municipale del 20 febbraio 1942 XX', 18 Apr. 1942.

${ }^{70}$ Ibid.

71 A number of Roman monuments were opened up by Italian architects at this time, the most prominent of these being Via dell'Impero, see Painter, jr, Mussolini's Rome, 22-5, for the Via dell'Impero, and 7-16 for initial projects, including the redevelopment of the Largo Argentina, the Teatro di Marcello and the Via del Mare. For a comprehensive account of the importance of Via dell'Impero, see Baxa, Roads and Ruins, 112-20; see also Kallis, The Third Rome. The 'Fascist' cities of the Pontine Marshes were also designed along the new principles of urbanistica; see F. Caprotti, 'Destructive creation: Fascist urban planning, architecture and new towns in the Pontine Marshes', Journal of Historical Geography, 33 (2007), 666-75. 
thereby allowing the new Italian community to flourish in a 'sanitary' environment. ${ }^{72}$ Yet these public works, non-essential during wartime, and particularly demonstrable as non-essential with a greatly reduced population, not only symbolize a desire to begin this project as rapidly as possible, but also the importance placed upon it.

In addition to applying Fascism's ideas of urbanistica and aesthetic changes, urban planners were determined to embark upon undertakings that would impact upon the standard of life of residents. Indeed, plans for overhauling and large-scale restoration were typically designed to enhance the lives of residents and future residents, rather than those that would have any immediate or long-term military impact. One programme that was earmarked for completion was the construction of a staircase from the Place de la Conception to the Basilica Saint Michel. This route had been noted as particularly steep and as such had limited access to the nearby cemetery. ${ }^{73}$ A proposed overhaul of the Place du Cap was designed to give the area a sense of 'monumentalità', providing a new 'entrance' for the town, which would open onto the extended boulevards that ran parallel to the sea. ${ }^{74}$ The construction of new and the overhaul of existing piazze were one example of Italian desires to beautify Menton, making the town more desirable for residents and tourists alike. During his tenure as civil commissioner, Frediani refitted the public gardens, using this project as part of an increasing drive for tourism. ${ }^{75}$ Indeed, as we have seen above, the construction of additional hotels and the insistence that adequate water be provided for all tourists to bathe regularly placed an increased, and unnecessary, burden on the already stretched water supply. ${ }^{76}$ In addition to this burden, however, engineers' estimates for usage included water to maintain the gardens. ${ }^{77}$

This aim of architecturally linking newly occupied territories with Italy was not limited to Menton. Indeed, Paolo Nicoloso's claim that no state placed as much political investment into architecture as Fascist Italy in the first half of the twentieth century is vindicated upon an examination of Italy's actions in its colonies both in Europe and Africa. ${ }^{78}$ In Rhodes, the Italian administration carried out similar policies, creating a large new section of the city which incorporated wide boulevards and valued the

72 Numerous housing projects in Rome were worded in the same manner; that the demolition of older housing would rid the city of disease and squalor, see Painter, jr, Mussolini's Rome, 91-3.

73 AMM 10272, 'Parere sul progetto di piano regolatore della città vecchia approvato con deliberazione municipale del 20 febbraio 1942 XX', 18 Apr. 1942.

$74 \mathrm{Ibid}$. Unfortunately, further details of this overhaul are not given, and it is unclear whether these were budgeted or were simply a long-term aim.

75 J.-L. Panicacci, 'Le tourisme à Menton durant les années noires (1939-1945)', Recherches Régionales, 200 (2011), 57.

76 Ibid.

77 ACS, CIAF, b. 2, fasc. 56, 'L'ingenere capo, S. Marletta, al Commissario Civile di Mentone', 24 Oct. 1940.

${ }^{78}$ Nicoloso, Mussolini architetto, xv. 
centrality of monuments. ${ }^{79}$ In both Rhodes and Kos, local residents noted that the development of an adequate water supply and improvements to sewers and drainage systems had been a priority for successive Italian governors. ${ }^{80}$ In Libya, debates existed between Italian urban planners on how best to create a 'Mediterranean' style of architecture, in order to foster links with Italy. ${ }^{81}$ As in Menton, the idea of sweeping away 'unhygienic' or 'squalid' housing became a central tenet of Italian urban planning overseas. The aforementioned drainage systems in the Italian Dodecanese were welcomed by local residents as improving public sanitation and local infrastructure. ${ }^{82}$ In the mid-1930s, Italian hygiene experts expounded the need to create a robust sanitation system in the redevelopment of Tripoli if the city were to flourish. ${ }^{83}$ Indeed, by 1937, the prominent Fascist Giuseppe Bottai claimed that urban planning was to the city as medicine was to the body. ${ }^{84}$ Despite the geographical distance between both Italy's colonies in the Dodecanese and in Africa, and Menton and the occupied French communes, strands of the same debates can be found in all three. In many cases, architects played an important role in suggesting how Fascism's newly acquired territories could be fused into a common Italian identity. Moreover, as Italian urban planners moved into these newly acquired territories, they imposed the science of urbanistica, proposing large-scale demolition and redevelopment in order to create supposedly 'hygienic' environments. In this way, the developments in Menton were no different to those found in Rhodes; as Davide Rodogno has stated, the spazio vitale must be thought of as a single project, as indeed many Italian expansionists believed. In this way, both Italian urban planning projects in Africa and the Dodecanese, as well as those in territories occupied during wartime, such as Menton, were part of the spazio vitale, and both were subject to the same urban planning projects. ${ }^{85}$

\section{Conclusion}

Italy's failure during World War II to make territorial gains on the scale of its German ally have often resulted in a failure to examine Italian actions in its zones of occupation, particularly in France. In Menton and the other

${ }^{79}$ N. Doumanis, 'Italians as "good" colonizers: speaking subalterns and the politics of memory in the Dodecanese', in R. Ben-Ghiat and M. Fuller (eds.), Italian Colonialism (Basingstoke and New York, 2005), 223-5. The centrality of monuments, or monumentalità, is specifically mentioned in AMM 1O272, 'Parere sul progetto di piano regolatore della città vecchia approvato con deliberazione municipal del 20 febbraio 1942 XX', 18 Apr. 1942.

80 Doumanis, 'Italians as "good" colonizers', 223-4.

81 B.L. McLaren, 'The architecture of tourism in Italian Libya: the creation of a Mediterranean identity', in Ben-Ghiat and Fuller (eds.), Italian Colonialism, 167-76. On the Mediterranean style, or mediterraneità, see Fuller, Moderns Abroad, 105-6.

82 Doumanis, 'Italians as "good" colonizers', 224-5.

${ }^{83}$ Fuller, Moderns Abroad, 164-5.

${ }^{84}$ G. Bottai, quoted in Kallis, The Third Rome, 55-6.

85 Rodogno, Fascism's European Empire, 273. 
occupied communes, Italian officials implemented a series of measures which revealed both the extent of Italianization policies carried out in the region, and strategies that may have been extended further into France had the Axis powers won the war. The integration of services and utilities in the town with those in the Italian peninsula went well beyond the necessary processes of restoring public life in Menton, and instead reveal the extent to which Italian officials viewed the communes as terra irredenta. These actions should be viewed as particularly unusual for an administration seeking solely to return the town to a status of merely functioning when one considers Italy's economic and military situation in 1942 and 1943. Long-term plans for the town expand this picture to at least 30 years after an Axis victory in the war.

Whilst Italian officials were only legally obliged under the Hague Convention to ensure the continuation of daily life, the measures taken by the Italian government went much further than this. The extent to which the town was integrated with Italy and the lengths to which Italian planners, engineers and administrators were willing to go to achieve this aim shows the extent of Italianization taking place. Although the vast majority of these plans did not come to fruition, they remain an important and underexamined indication of Fascism's ambitions in post-war Europe. Importantly, many of these plans echoed what the Fascist government had begun or achieved in urban planning projects and ambitions in Italy. Fascist planners were, therefore, victims of their own making: it would have been perfectly possible to come to arrangements with French and Swiss companies, or indeed to impose measures to limit the available daily water supply per person. Instead, local officials not only pursued a policy of encouraging the return of the pre-war population, but also simultaneously refusing to introduce any form of curtailment on the free and limitless availability to water and other facilities. Much of this hubristic approach stemmed from the concept that the Axis would win the war, which would give the Italian government a free hand to carry out their policies. Whilst it is, of course, impossible to know what policies may have been carried out in France had larger territorial gains been made at the end of the war, these blueprints are examples of urban planning beyond the peninsula and demonstrate larger-scale Fascist hopes for the spazio vitale. 